\title{
Post-harvest enzymatic activities of healthy and infected Cassava (Manihot esculenta Crantz) tubers
}

\author{
Salami, A. O. ${ }^{1}$ and A. K. Akintokun ${ }^{2}$ \\ ${ }^{1}$ Department of Plant Science, Obafemi Awolowo University, Ife, Nigeria. ${ }^{2}$ Department \\ of Microbiology, College of Natural Sciences, University of Agriculture, Abeokuta, \\ Nigeria
}

\begin{abstract}
Post-harvest rot of tubers of three cassava (Manihot esculenta Crantz) cultivars namely TMS 4(2)1425 (hybrid cultivar); and 2 local cultivars Oko-Iyawo and Odongbo) were surveyed in Southwestern Nigeria. A total of ten fungal organisms were isolated from rotted cassava tubers collected from eight towns in four states in Southwestern Nigeria. The most frequently isolated and pathogenic ones which were used in this study as the test pathogens are Lasiodiplodia theobromae; Macrophomina phaseolina; Rhizopus stolonifer; and Fusarium pallidoroseum,. Their cell wall degrading enzymes which are cellulase; amylase; polygalacturonase (PG); and pectin methyl esterase (PME) were also assayed. In all the three cultivars inoculated with each of the test pathogens, enzyme activities were found to increase with the incubation period between 6 and 8 days of inoculation and declined at day 10. The peak of enzyme activities declined at different periods for all the cultivars used. PME and PG activities were found highest in cultivar TMS 4(2) 1425 and least in Odongbo cultivar.Test pathogens also behaved differently when inoculated with the culture filtrates of the different enzyme activities. M. Phaseolina was found highest while $F$. pallidoroseum was the least in all the enzyme activities cultured except in pectin methyl esterase where Lasiodiplodia theobromae had the highest activity. Mycelia dry weight of the test pathogens were also found to increase with incubation period with $F$. pallidoroseum having the highest mycelia mats while L. theobromae had the least. Enzyme production and activities of the test pathogens in the utilization of the carbon sources varied with the different carbon sources and the test pathogens. All the test pathogens produced enzymes and had activity but at different levels.Generally, enzyme activities showed the rate of maceration of tissues and the extent of rot disease of cassava tubers as well as the aggressiveness and pathogenic abilities of the test pathogens.
\end{abstract}

Keywords: Post-harvest, enzymatic activities, pathogen, food crop, mycellial weight.

$$
\begin{aligned}
& \text { النشاط الأنزيمي لدرنات الكسافا (Manihot esculenta Crantz) السليمة } \\
& \text { والمصابة بعد الحصاد } \\
& \text { أ.و. سلامي 1؛ أ.ك. أكونتكن2 } \\
& \text { 1قسم علم النبات، جامعة اوبافيمي أولوا، اف، نيجيريا؛ ققسم الاحياء الدقيقة، كلية الموارد الطبيعية، الجامعة الزراعية، } \\
& \text { أبيكوتا، نيجيريا }
\end{aligned}
$$




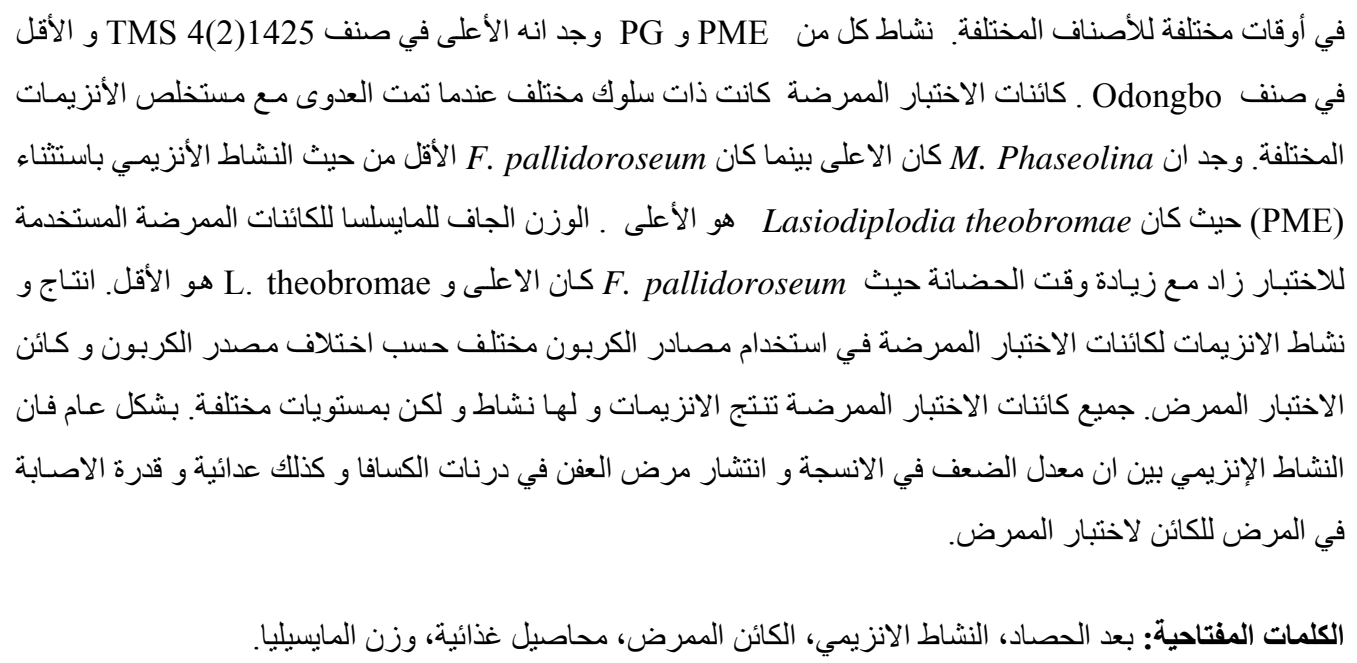

\section{Introduction}

Cassava (Manihot esculenta Crantz), is among the prominent tuber crops in the tropical and subtropical world while Nigeria is currently one of the largest world producers. It is grown for its starchy tuberous roots which can be used for the production of ethanol, glucose, starch, alcohols, gums and pastes for industrial uses (Adewolu, 1999). It is a valuable source of calories, particularly for low-income earners (IITA, 1990). It is consumed as a staple food by almost 400 million people in the humid and semihumid tropics of Africa, Asia, and America. Farmers in Africa have long recognized the value of cassava as an insurance crop against famine and food shortage. Its real value lies in its hardy climates; therefore ensuring domestic food supplies against crop failure, it adapts well to adverse environmental conditions, it thrives in sandy-loam soils with low organic matter and climates characterized by low rainfall and high temperature (Wanapat et al., 1997; FAO, 2000) but this does not mean that cassava is a crop of poor environmental conditions (Awah, 1993 \& Salami and Osonubi, 2002). For any person living on marginal land, it may be the only crop that yields a year-round harvest (UNICEF/IITA, 1989). Cassava contributed $14 \%$ of the average daily dietary energy intake per person in
Nigeria, the fourth largest contributor after sorghum (22\%), millet (19\%), and yam $(15 \%)$ (FAO, 1991) as quoted by Felix et al. (1999).

Conditions such as poor soils, use of local varieties, land tenure and damage by pests and diseases, have kept the production of cassava below its full potential in Africa (Dahniya, 1994; FAO, 2000). But recently, there has been new re-awakening regarding cassava production in Nigeria with the establishment of a national committee to facilitate the transformation of cassava to a product for export. This means that all factors that might have been inhibiting its production and yield have to be given a renewed attention. The roots of cassava are highly perishable when compared with the other root crops. They deteriorate and senesce rapidly after being detached from the plant and they cannot be kept for a long time (Padmaja and Balagopal, 1985; Salami, 2002). The length of time for which the roots may be held differs according to cultivars' temperature and the end use to which the roots are to be put e.g. in the manufacture of high grade starch, the roots should be processed within $24 \mathrm{hrs}$ of harvest. Dahniya (1994) and Odebode and Shehu, (2001) reported that the main biological constraints in cassava production in Africa are diseases and pests. The extent 
of loss may be as high as $90 \%$ or there may be total failure (Lozano and Booth, 1974). Ingram and Humphries (1972) and Salami and Osonubi (2002) observed that spoilage of cassava roots arises from a combination of physiological and pathological factors. Studies have shown that primary deterioration is essentially a wound response with increase in enzyme and phenol production (Odebode et al., 1997, 2001). Two distinct types of deterioration have been noticed in cassava tubers: which are soft and dry rots. Biochemical analysis of infection process which showed that the microbial plant pathogens must produce a set of enzymes capable of attacking the carbohydrate polymers and protein composition of the infected plant's cell wall (Paolo and Franceso, 1995; Odebode et al., 2001). These enzymes are either intracellular or extracellular (Onyeocha and Ogbonna, 1983; Lealam and Gashe, 1994). The intracellularly produced enzymes are insoluble pectic polymers which cement the plant cells together, they include: Cellulase, amylase and pectinolytic enzymes. Cellulase, which is a cell wall degrading enzyme found within the tissue of plants and it is capable of tissue maceration especially when secreted by pathogens (Perez-Artes and Terra, 1989; Olsson, 1989; Salami et al., 2001). Amylase plays an important role in the degradation of starch tissue and it is involved in the breakdown of large starch molecules to simple sugars (Oguntimehin and Safarik, 1993; Odebode et al., 2001). Pectinolytic enzymes are also involved in hostpathogen interactions by degrading the middle lamella and cell walls leading to tissue maceration. This degradation and breakdown lead to loss of tissue coherence, separation of individual cells and finally, reduced food production. Hence, this study reveals the cellulase; amylase and pectinolytic enzymatic activities in tubers of three cassava cultivars after harvest.

\section{Materials and Methods}

Survey and Collection of samples was carried out in eight farms located in various parts of Southwestern Nigeria. These include: Ajibode in Akinyele local government and Eruwa in Ibarapa local government, both of Oyo State; Ede in Ede local government and Ilobu in Egbedore local government of Osun state; Odeda in Odeda local government and Ilaro in Yewa local government of Ogun state; and finally, in Akurein Akure local government and Ondo of Ondo local government of Ondo State. Out of the heaps of cassava tubers harvested, 2 tubers per farm were randomly selected depending on the size of harvest. These tubers were inspected for rotted areas, which were carefully cut and stored in clean and sterilized polyethylene bags for laboratory analysis.

Isolation of the associated fungi was done by excising ( $4 \mathrm{~mm}$ pieces) of the diseased samples followed by surface sterilization with 1\% Mercuric Chloride solution for I minute before rinsing in five successive changes of sterile distilled water. They were finally blotted dry in order to remove excess water. These specimens were then plated on Potato Dextrose Agar (PDA) and were incubated at $30^{\circ \mathrm{c}}$ for 24-72 hours. On the emergence of mycelial colonies, the organisms were sub-cultured onto fresh sterilized PDA plates in order to obtain pure colonies while the slants were kept in McCartney bottles and stored in a refrigerator for future use.

Each mycelial colony was aseptically taken using sterilized inoculating needle onto a clean microscope slide and teased in a drop of lacto phenol cotton blue. The species of fungi that grew on the plates were identified with the aid of a compound microscope and those in the standard test (Barnetts and Hunter, 1972). These isolates were also compared with the standard isolates obtained from the Tuber Root Improvement Programme 
Pathology Laboratory (TRIPPL), IITA, Ibadan, Nigeria. Pathogenicity of isolated fungi was established by testing for their ability to induce rot in healthy tubers. The tubers were cut into 2 or 3 pieces depending on the length of the tuber to shorten the length. To prevent further infection, cut ends were sealed with paraffin wax. The tuber pieces were swabbed with ball of cotton wool soaked in $1 \%$ Mercuric Chloride and then washed thrice with running tap water. Holes were dug in these tubers by using $5 \mathrm{~mm}$ diameter cork-borer and the plug was pulled out and exchanged with $3 \mathrm{~mm}$ diameter mycelia disc of each test pathogen by placing it at the bottom of the hole. Small portion of the plug were cut off to compensate for the thickness of the mycelia disc introduced into the hole. The plug was carefully placed and the wounded area sealed with vaseline to prevent extraneous infection. They were then incubated for $2,4,6,8$, and 10 days respectively at $30^{\circ} \mathrm{C}$. All these were done in three replicates while the control experiment was done with sterilized PDA discs of equal diameter made into the holes of the healthy tubers. At the end of the tenth day, the tubers were cut across by means of sterilized scalpel along the plane of inoculation before assessing the rot percentage which was carried out using rot indices ranging from 0-10. Pathogenic index for each fungus was determined by using this expression: Pathogenic Index $(\mathrm{PI})=100-[\underline{\mathrm{DWD} X}$ $\underline{100]}$

\section{DWH}

Where: DWD $=$ Dry weight of diseased tuber; and DWH = Dry weight of healthy tuber. Fungi with the highest pathogenic indices were used for further tests.

\section{Enzyme Studies}

This was done in both in-vivo and invitro. In-vivo involved the use of healthy and diseased tubers while in-vitro involved the use of culture filtrate. The activities of cellulase, amylase, polygalacturonase and Pectin Methyl
Esterase were determined in healthy and diseased tubers (in- vivo) and culture filtrate (in-vitro). Enzyme activities were determined in fresh tubers and in those stored at ambient conditions $30^{\circ \mathrm{cc}}$ for 2,4 , 6,8 , and 10 days in all the three varieties used for this study. The tubers were peeled and washed with water while the adhering water was removed by blotting paper. Two grams of sliced samples were transferred to chilled mortar, minced, and extracted with $10 \mathrm{ml}$ of respectively cooled buffers. The extracts were centrifuged at $3000 \mathrm{rpm}$ for $10 \mathrm{~min}$. and the clear supernatant was precipitated with saturated ammonium sulphate. The precipitate was filtered and the filtrate further dissolved in respective buffers. The resultant solution obtained was dialyzed for 24hours using a dialyzing tube. The resulting solution was then stored at $-10^{\circ} \mathrm{C}$ until required for appropriate enzyme assay.

In-vitro enzyme study was carried out using culture filtrates. Five day old cultures of the fungal isolates $L$. theobromae; $M$. phaseolina; $R$. stolonifer; and $F$. pallidoroseum grown on PDA were used. The basal medium used to grow the fungal isolates consisted of yeast extract $0.1 \mathrm{~g} \quad \mathrm{KH}_{2} \mathrm{PO}_{4} ; \mathrm{g}$ $\left.\mathrm{MgSO}_{4} .7 \mathrm{H}_{2} \mathrm{O} ;\right) .5 \mathrm{~g} \mathrm{NaNO}_{3} ; 5 \mathrm{~g} \mathrm{FeCl}_{3}$ and $0.001 \mathrm{~g}$ in 1 liter of distilled water and $0.1 \%$ soluble starch. $25 \mathrm{ml}$ of the basal medium were dispensed into several $150 \mathrm{ml}$ conical flasks and then sterilized at $121 \mathrm{C}^{\mathrm{o}}$ at $1.05 \mathrm{~kg} / \mathrm{cm}^{2}$ for 15 minutes. After cooling, each of the extract was inoculated with $5 \mathrm{~mm}$ mycelial disc of the test organism and incubated at $30^{\circ \mathrm{c}}$ for $2,4,6,8$ and 10 days. The mycelial mats observed were filtered with paper and the filtrates collected for enzyme assay. Cellulase activity was carried out according to the methods of Somogyi (1952) and Nelson (1944) as modified by Ooshima et al. (1986) while Amylase activity was done using Bernfeld (1951) as modified by Adewolu (1999). Polygalacturonase was also assayed for in 
this work using the method of Jansen and Macdonell (1945) as modified by Odebode et al. (2001) while Pectin Methyl Esterase activity was carried out according to the method of Winstead and Walker (1954) as modified by Salami (1999).

Effect of different carbon sources on the mycelia growth of fungal isolates and enzyme activities was investigated in this study. The carbon sources used are Pectin (Pec); Soluble Starch (SS); and Carboxyl Methyl Cellulose (CMC). The basal medium consisted of yeast extract $0.1 \mathrm{~g}$ $\mathrm{KH}_{2} \mathrm{PO}_{4} ; 1 \mathrm{~g} \mathrm{MgSO}_{4} ; 1 \mathrm{~g} \mathrm{MgSO}_{4} .7 \mathrm{H} 2 \mathrm{O}$; $0.5 \mathrm{~g} \mathrm{FeCl}_{3} ; 0.001 \mathrm{~g}$ in 1 liter of distilled water. The amount of carbon sources tested per liter was $10 \mathrm{~g}$ each of them to obtain Pectin broth (PTB); Soluble Starch broth (SSB); and Carboxyl Methyl Cellulose broth (CMCB). Each broth was dispensed into $150 \mathrm{ml}$ conical flasks and autoclaved at $121^{\circ} \mathrm{C}\left(1.05 \mathrm{~kg} / \mathrm{cm}^{-2}\right)$ for 15 minutes.

\section{Results}

Lasiodiplodia theobromae; Macrophomina phaseolina; Rhizopus stolonifer; Fusarium pallidoroseum; and Aspergillus niger were isolated from all the experimental locations. Sclerotium rolfsii and Penicillium spp. were isolated from Ajibode farm (Oyo State) but were absent in other sites. Aspergillus flavus was isolated from Ajibode; Akure and Eruwa. Phytophthora palmivora occurred at Ajibode farm, Eruwa and Owena sites but was absent in all the other experimental sites while Fusarium solani occurred only at Ajibode; Ede and Odeda (Table 1). Lasiodiplodia theobromae and Rhizopus stolonifer had the highest percentage of pathogenic indices (96\%) followed by Macrophomina phaseolina and Fusarium pallidoroseum with $83 \%$ and $80 \%$ respectively and least was Penicillium spp.(5\%) (Table2).

\section{Establishment of Pathogenicity}

All the fungi isolated from rotted cassava tubers were pathogenic but Lasiodiplodia theobromae was the most pathogenic, followed by Rizhopus stolonifer while Penicillium specie was the least pathogenic (Table 2). $L$. theobromae (with the exudation of pungent smelling liquid) and $R$. stolonifer (with the exudation of sweet smelling liquid) caused almost total rot in cassava tubers within 5 days of inoculation while Macrophomina phaseolina and Fusarium pallidoroseum caused total rot of the tubers within 8days of inoculation without exudation of liquid (Table 2). All other fungal organisms caused between $0.5 \%$ and $3 \%$ rot of the total surface area of the inoculated tubers within the same number of days of inoculation.

Table 1. Occurrence of fungi associated with tuber rot of cassava in Southwestern Nigeria.

\begin{tabular}{lcccccccc}
\hline Fungal organism & Ajibode Farm & Eruwa & Ilobu & Ede & Odeda & Ilaro & Owena & Akure \\
\hline L. theobromae & + & + & + & + & + & + & + & + \\
R. stolonifer & + & + & + & + & + & + & + & + \\
M. phaseolina & + & + & + & + & + & + & + & + \\
F. pallidoroseum & + & + & + & + & + & + & + & + \\
F. solani & + & - & - & + & + & - & - & - \\
A. niger & + & + & + & + & + & + & + & + \\
A. flavus & + & + & - & - & - & - & - & + \\
S. rolfsii & + & - & - & - & - & - & - & - \\
P. palmivora & + & + & - & - & - & - & + & - \\
Penicillium specie & + & - & - & - & - & - & - & - \\
\hline
\end{tabular}

+: Fungi present - :Fungi absent 
Table 2. Pathogenicity test of fungi isolated from rooted cassava tubers.

\begin{tabular}{lcl}
\hline Fungal Organisms & Pathogenic indices (\%) & \multicolumn{1}{c}{ Remarks } \\
\hline L. theobromae & 96 & $\begin{array}{l}\text { Wet rot with pungent smelling liquid } \\
\text { (after 5 days of inoculation) }\end{array}$ \\
R. stolonifer & 96 & $\begin{array}{l}\text { Wet rot with sweet smelling liquid } \\
\text { (after 5 days of inoculation) }\end{array}$ \\
M. phaseolina & 83 & $\begin{array}{l}\text { Dry rot (after 8 days of inoculation) } \\
\text { Wet rot without liquid exudation (after } 8 \\
\text { Fays of inoculation) }\end{array}$ \\
F. solani & 80 & Dry rot (after 8 days of inoculation) \\
A. niger & 75 & Dry rot (after 8 days of inoculation) \\
A. flavus & 40 & Dry rot (after 8 days of inoculation) \\
S. rolfsii & 33 & Dry rot (after 8 days of inoculation) \\
P. palmivora & 12 & Dry rot (after 8 days of inoculation) \\
Penicillium specie & 10 & Dry rot (after 8 days of inoculation) \\
\hline
\end{tabular}

Enzyme activities of both infected and healthy tubers of the three cultivars

Amylase activities of both healthy and infected tubers at different incubation period showed that there was gradual increase in the activity. Healthy cassava tubers of the three cultivars had the peak of amylase activity at different days, cultivars TMS 4(2) 1425 and Oko-Iyawo had theirs on the $4^{\text {th }}$ day of incubation while Odongbo had its own on the $8^{\text {th }}$ day of incubation (Figure 1 and 2). Infected tubers of the three cultivars had amylase activities, which increased gradually from day 1 to day 8 and declined at day 10 (Figure 2) . In general, amylase activities of the infected tubers were greater than the activities of the healthy tubers with $L$. theobromae infected tubers having the highest amylase activity (Figure 1 and 2). Cellulase activities of healthy tubers of the three cultivars rose at different times after incubation. In Odongbo cultivar, it increased till the $4^{\text {th }}$ day then started declining while cultivar TMS 4(2) 1425 had increase till the $6^{\text {th }}$ day before it declined. Oko-Iyawo cultivar had increased cellulase activity with the increase in incubation time throughout the experiment (Figures1 and 2). Infected tubers also had cellulase activities which increased between $6^{\text {th }}$ and $8^{\text {th }}$ days, but declined thereafter (Figure 2). In all, Lasiodiplodia theobromae had the highest cellulase enzyme activity among the three cultivars.

Polygalacturonase (PG) activity changes were observed in healthy tubers in all cultivars used (Figureland 3). In cultivar TMS 4(2)1425, PG activity rose to its optimum on the $4^{\text {th }}$ day and declined subsequently to the $10^{\text {th }}$ day when the experiment was terminated. Odongbo and Oko-Iyawo cultivars had increased PG activities up to the $8^{\text {th }}$ day and started declining from then to the $10^{\text {th }}$ day but TMS 4(2)1425 had the highest PG activity among the healthy tubers (Figure1). Infected tubers also had PG activities which increased gradually till the $8^{\text {th }}$ day but declined thereafter (Figure1 and 3). Cultivar TMS 4(2)1425 had the highest PG activities among the infected tubers. Pectin Methyl Esterase (PME) activities were found identical and at the peak in both the infected and healthy tubers with the highest activity observed in TMS 4(2)1425 and least in cultivar Odongbo (Figure 1 and 3). They all gradually declined from the $6^{\text {th }}$ day till the $10^{\text {th }}$ day.

Correlation between disease index and loss in dry matter content of the infected tubers against their enzyme activities was observed in this study. The results showed that for all the test pathogens and extra cellular enzymes used in this study, the loss in dry matter content and enzyme 
activities were positively correlated with high significance at less than 5\% level of probability (Figure 1 and 4). Mycelial dry weight of the test pathogens was found to increase with the incubation period (Figure1 and 4) but differences were observed when their different enzymes were assayed. Pattern of changes in amylase activities of the test pathogens were found similar with a gradual increase from $1^{\text {st }}$ day to $8^{\text {th }}$ day and decrease till $10^{\text {th }}$ day. Amylase activity was found highest in Macrophomina phaseolina (Figure 1 and $2)$. Cellulase activities of the test pathogen also took a pattern where $L$. theobromae and $R$. stolonifer had increase in their activities till the $4^{\text {th }}$ day and declined gradually from then till day 10. Whereas, F. pallidoroseum had increase till the $6^{\text {th }}$ day and declined sharply, resulting in the least cellulase activity. M. phaseolina had increased cellulase activity throughout the incubation period and thus, had the highest cellulase activity (Figure 1 and 2). M. phaseolina and L. theobromae had increased PG activities till the $4^{\text {th }}$ day and decreased thereafter with the incubation period while PG activities in $R$. stolonifer and $F$. pallidoroseum were undulating with the activities found to decrease till the $4^{\text {th }}$ day and increased from then till the $6^{\text {th }}$ day but finally decreased till $10^{\text {th }}$ day (Figure 1 and 2). Pectin Methyl Esterase activity of the test pathogens increased with incubation period throughout the experiment with $L$. theobromae having the highest PME activity (Figure 1 and 3 ).

Utilization of the different carbon sources and enzyme activities by the test pathogens' mycelia dry weights was determined in this study and it was found to be differently utilized by the test pathogens (Figure 1 and 4). The carbon sources used were: Pectin (Pec); Soluble Starch (SS); and Carboxyl Methyl Cellulose (CMC). All the test pathogen grew well on these carbon sources but the best growth was observed on Pec followed by SS and $\mathrm{CMC}$ with the least growth. $R$. stolonifer had the highest growth on Pec followed by $L$. theobromae while $M$. phaseolina had the least growth on it. M. phaseolina had the best growth on SS followed by $F$. pallidoroseum and L. theobromae had the least growth (Figure 1 and 4). $L$. theobromae had the highest mycelial mat growth on CMC whereas; $R$. stolonifer had the least growth. Their levels of significant differences in the utilization was less than $5 \%$ level of probability and the filtrate obtained from the carbon source was used to assay for their enzyme activities. These test pathogens were able to produce amylase enzyme activities on Pec; SS; and CMC. On Pectin broth, L. theobromae had the highest activities while $R$. stolonifer had the lowest amylase activity. On SS broth, amylase activity of $M$. phaseolina was found highest followed by $R$. stolonifer while the least activity was found in $L$. theobromae. On CMC, L. theobromae and $M$. phaseolina had the same and highest amylase activities while the least was recorded in $R$. stolonifer (Figure 1 and 4). Considering the three carbon sources, the highest cellulase enzyme activity was produced by $M$. phaseolina on Pec and SS broths while the lowest activity was found on CMC broth (Figure.1 and 4). All the test pathogens tested positive and had PG activities but $L$. theobromae had highest activity on Pec and SS while on CMC, $L$. theobromae; M. phaseolina; and $F$. pallidoroseum recorded the same and least PG enzyme activity (Figs 1\&.4). PME activity produced by $L$. theobromae on Pec broth was found highest while $M$. phaseolina produced the least activity on SS broth. On CMC M. phaseolina gave the highest PME enzyme activity while $L$. theobromae; $R$. stolonifer and $F$. pallidoroseum gave the same PME enzyme activity (Figure 1 and 4). 


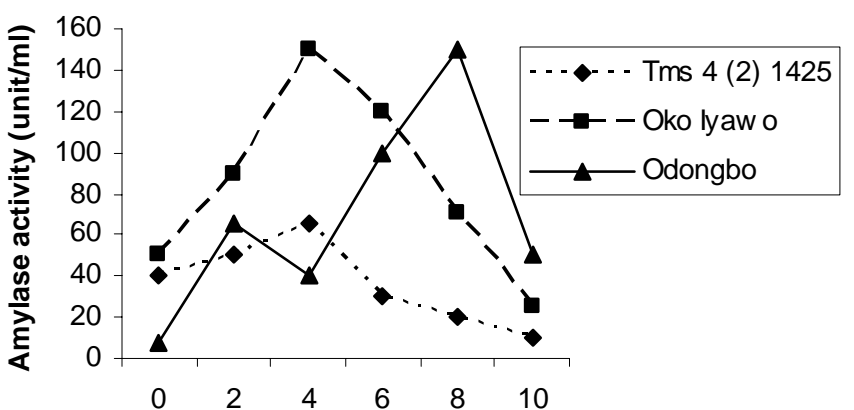

Period of storage (in days)
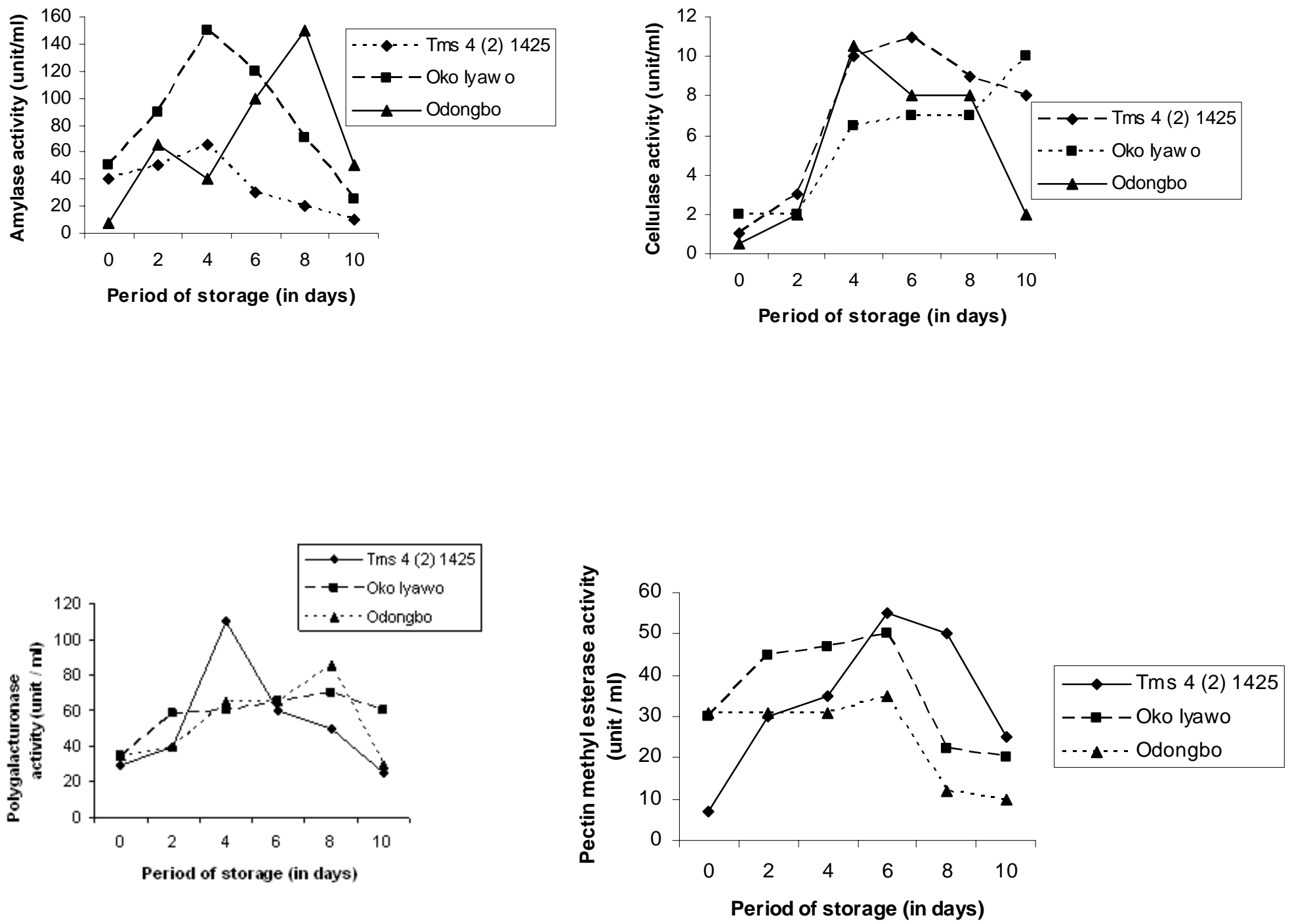

Figure 1. Change in extra-cellular enzymes' activities in healthy tubers of cassava during storage. 
Emir. J. Food Agric. 2008. 20 (1): 01-17

http://www.cfa.uaeu.ac.ae/research/ejfa.htm

TMS 4 (2) 1425 variety

हె
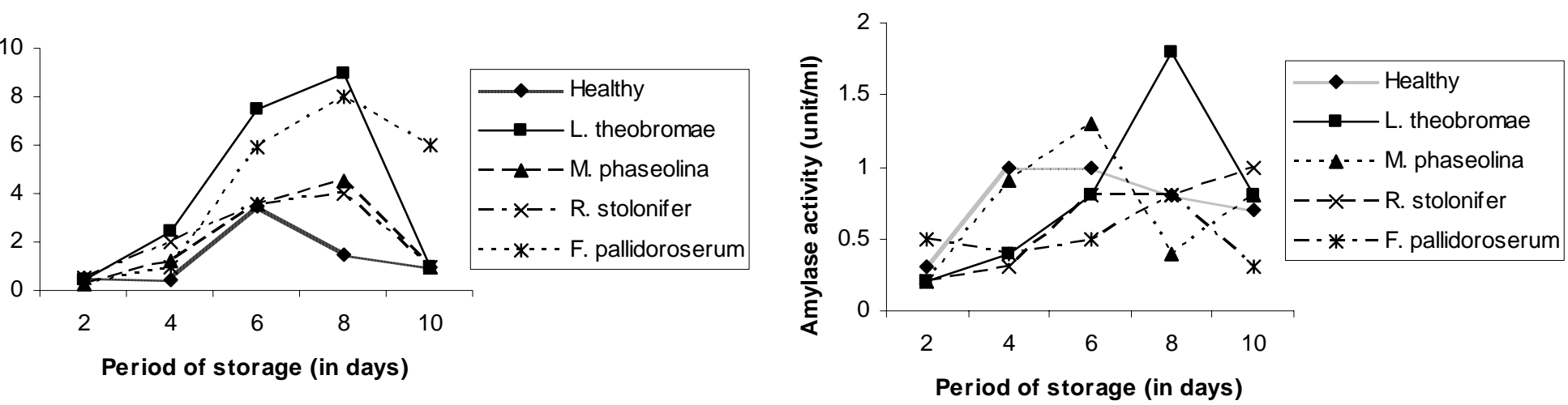

Oko-Iyawo variety
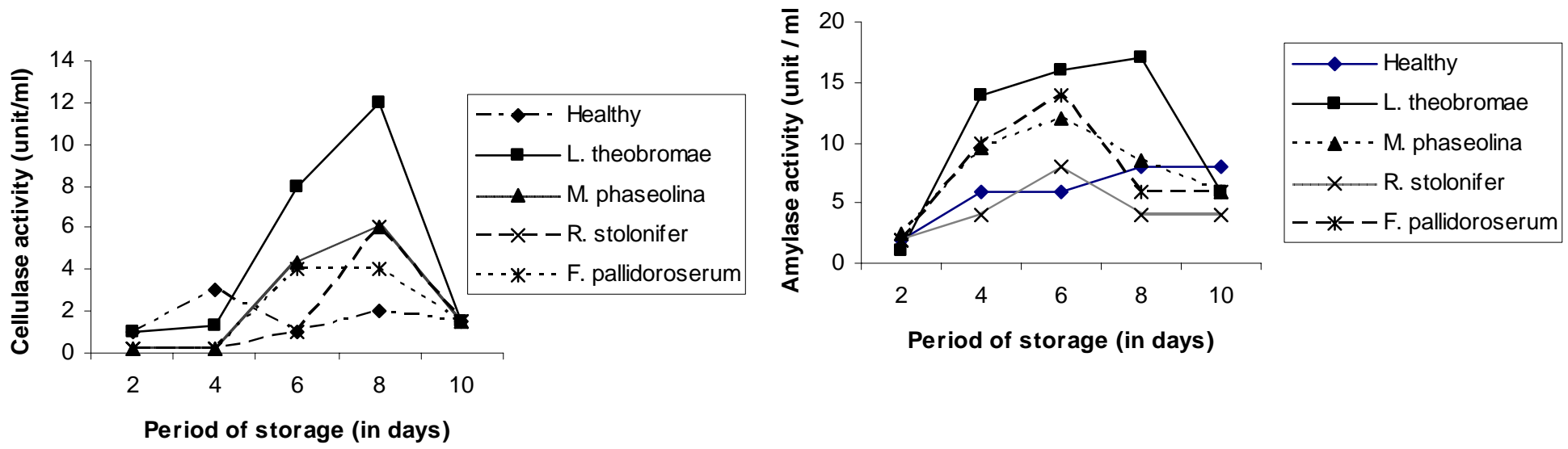

Odongbo variety
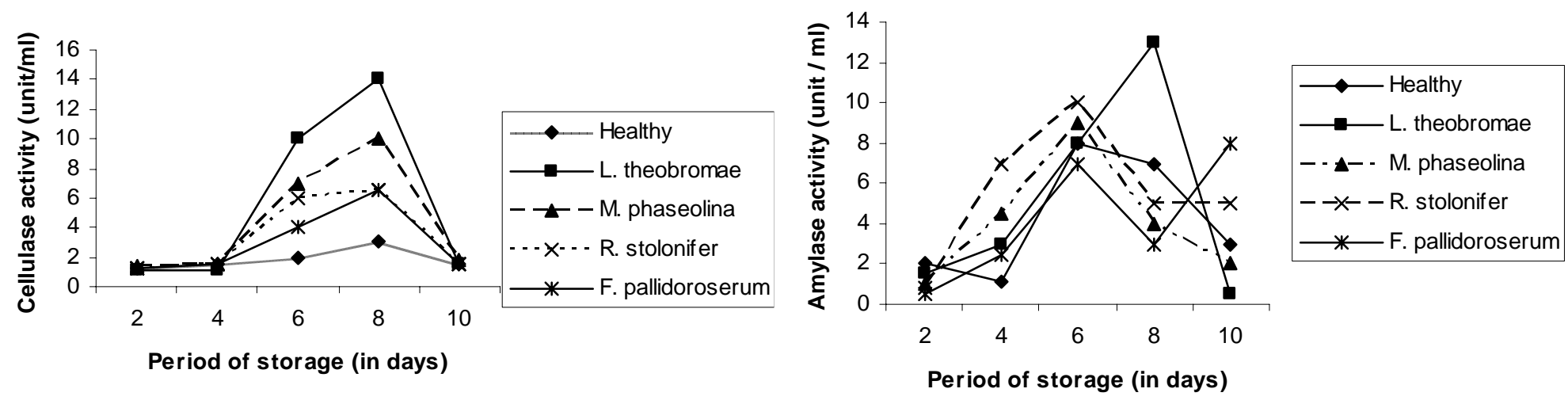

Figure 2. Amylase and Cellulase enzymatic activities of cassava in healthy and infected tubers during storage. 
Salami, A. O. and A. K. Akintokun

TMS 4 (2) 1425 variety
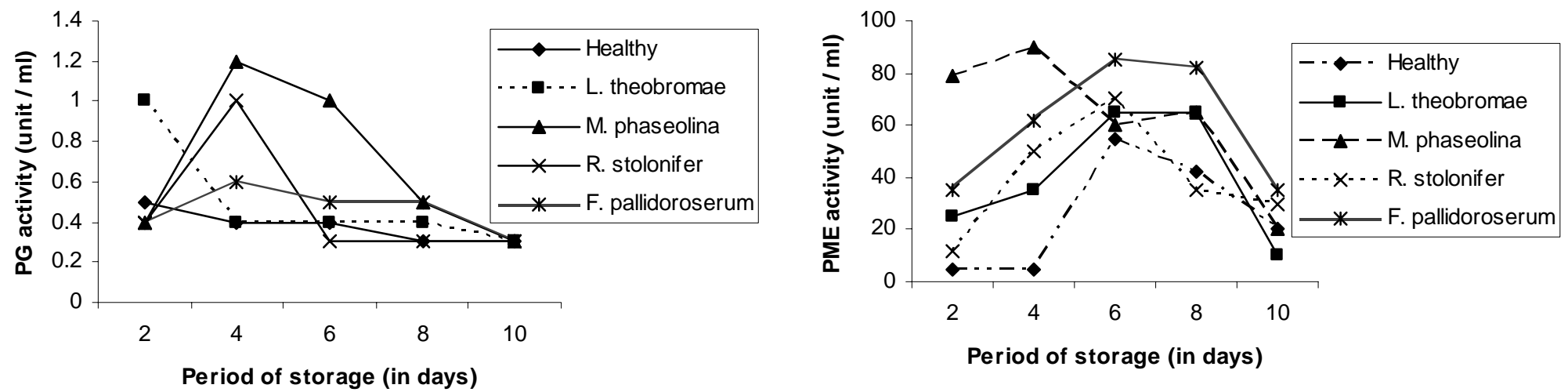

Oko - Iyawo variety

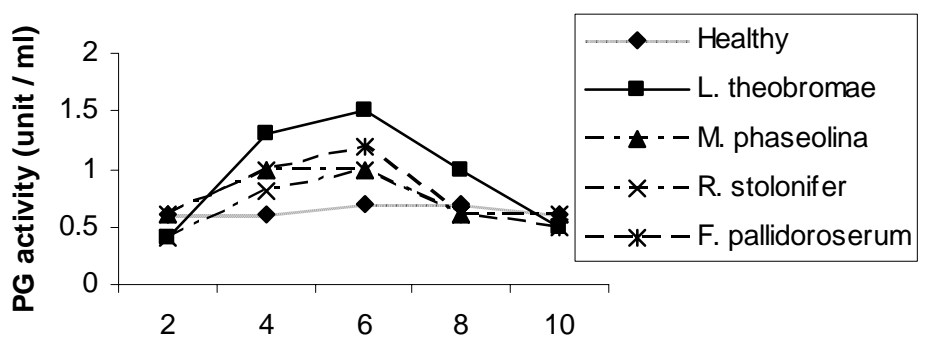

Period of storage (in days)

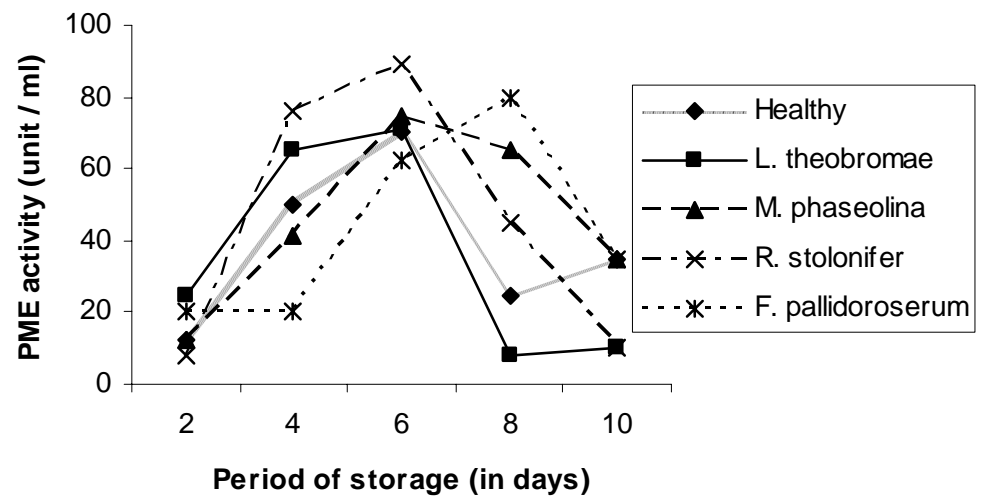

Odongbo variety


Figure 3. Polygalaturonase (PG) and Pectin methyl esterase (PME) enzymatic activities in healthy and infected tubers of three cassava cultivars. 
Emir. J. Food Agric. 2008. 20 (1): 01-17

http://www.cfa.uaeu.ac.ae/research/ejfa.htm
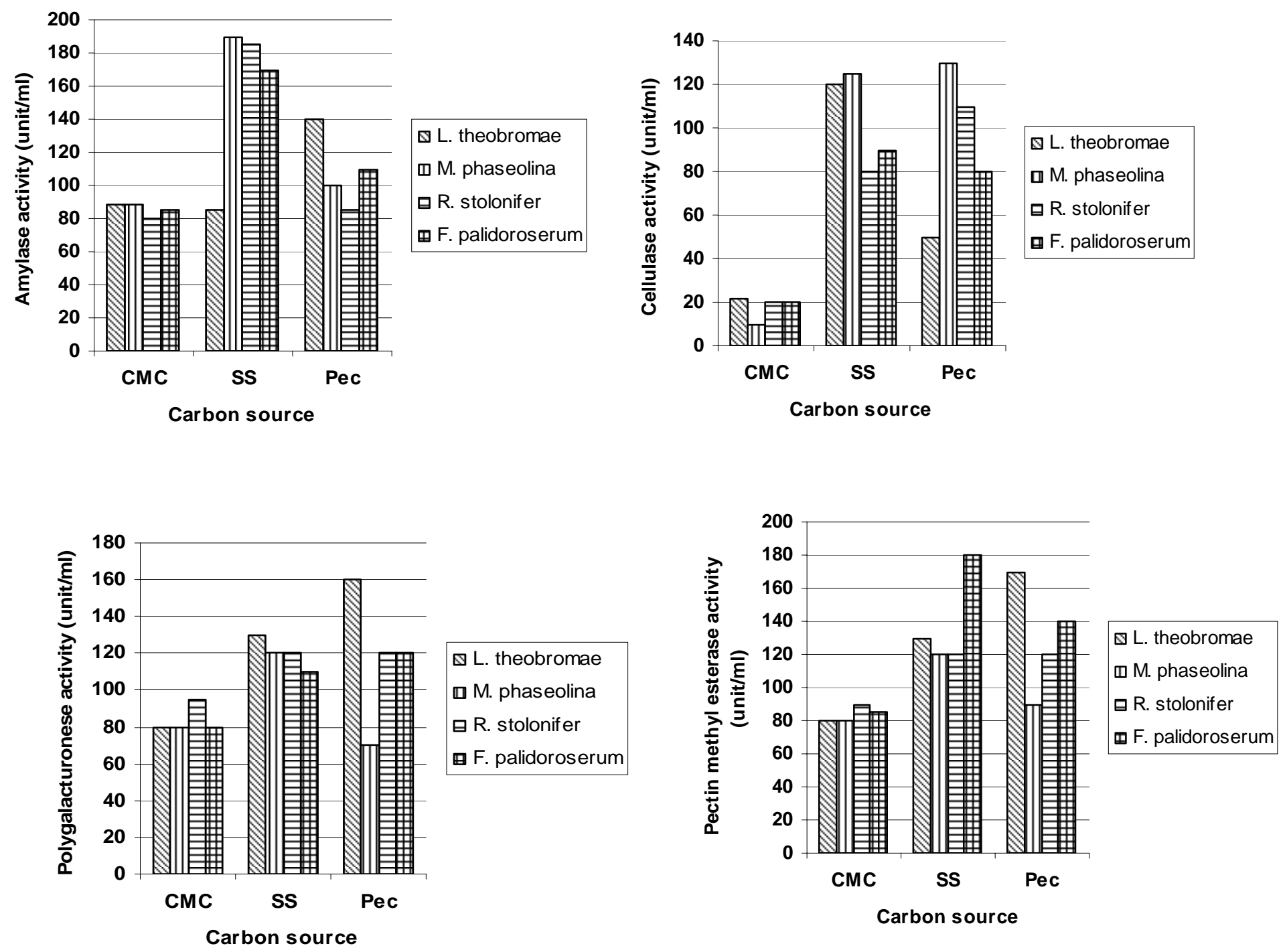

Key

CMC- Carboxyl Methyl Cellulose

SS - Soluble Starch

Pec - Pectin

Figure 4. Mycelia dry weight of the test pathogens and enzyme activities showing the utilization rate of different carbon sources. 


\section{Discussion}

Occurrence and activities of some micro-organisms causing rot disease of some staple food crops especially tubers are becoming menace and thorn in the flesh of the movement for food security in the tropics. This has been established in this study when surveys on the importance of microorganisms causing rot disease of cassava tubers in storage were conducted in three states of Southwestern part of Nigeria. The organisms isolated from this survey were in line with what IITA (1990) isolated when a similar survey in Ghana; Benin; and Cameroun was conducted. These were also isolated by Tella (1991) and Adewolu, (1999) from rotted cassava tubers. Fungal organisms isolated from this study have been found to be ubiquitous and cosmopolitan because they were able to colonize a wide range of habitats being not restricted to cassava tubers only but other tubers. This was reported by Arinze (1974); Duran and Mora (1992) and Ajiboye (2004). Pathogenicity test results indicate that all the fungi isolated from the infected tubers were pathogenic. This is in line with the results of Odebode and Salami (2004) in their work showing the effect of Pythium aphanidermatum and Sclerotium rolfsii on Tomato and Pepper. Rot disease observed in this study appeared to be the total or gradual breakdown of parenchyma especially of storage tissue such as cassava tubers used in this study. It is also typical of collenchyma breakdown, in which the causative organisms take the form of rapidly spreading the lesions which may or may not be discoloured (Wood, 1971 and Salami et al., 2001). This was observed in this study as the infection caused by L. theobromae and R. stolonifer started with discolouration of the infected area which was followed by gradual softening and subsequent production of watery fluid with offensive odour to indicate the breakdown of the parenchyma and collenchyma. This was also observed by Salami (1999); Adewolu (1999); Ajiboye (2004) and Popoola (2006). Histological studies showed that the softening of the host tissue was as a result of disintegration of the host's cell walls and the collapse of the infected tissues (Therberge, 1989). In this study, severe rot observed in Odongbo and TMS 4(2)1425 cultivars infected with the pathogens reveals that they were more susceptible than the Oko-Iyawo cultivar which was moderately susceptible to infection by the test pathogens. This was opined by Ikotun (1984); Perez-Artes and Tera (1989); and Oladiran and Oluma (1990).

Fungi produce an array of enzymes which are of prime importance and are related to the substrate they colonize. This was established in this work as the extra cellular enzymes produced were capable of breaking down the tissues of the storage products (cassava) from starch to maltose (Odebode et al., 2001). Activity of the amylase enzyme in both healthy and infected tubers of the three cultivars used in this study could be due to complete hydrolysis of starch molecules, this was found greater in infected than in healthy tubers because of the total exhaustion of the starchy materials. Odebode and Sanusi (1996) and Salami (1999) reported that extra cellular amylase plays a significant role in the breakdown of starch to sugar in cassava tuber after harvest, hence, the increase in its activity in the infected compared to healthy cassava tubers used in this study. Activity of the cellulase enzyme in this study shows the extent of cell wall degradation and the ability to utilize cellulose. This was found higher in infected tubers than in the healthy tubers due to the aggressiveness of the test pathogens. It has been reported by Reese and Mandel (1963); Adewolu (1999) and Popoola, (2006) that cellulase is involved in cell wall degradation, hydrolyzing 
Emir. J. Food Agric. 2008. 20 (1): 01-17 http://www.cfa.uaeu.ac.ae/research/ejfa.htm

cellulose to cellbiose both in its native and crystalline states Padmaja et al. (1994) and Padmaja and Balagopal (1985) also found that Rhizopus oryzae produced cellulases capable of degrading the cassava tuber cellulose

Pectinolytic enzymes constitute the major group of cell wall degrading enzyme; they are polygalacturonase and pectin methyl esterase. They are involved mainly in the catabolism as well as the solubility of the polysaccharides and also in tissue maceration which leads to rot disease. This was also observed in this work, as there were different forms of rot diseases (i.e. wet, dry rots) produced by the different test pathogens used for this study and Agrios (1998); Ampe and Brauman (1995) and Odebode et al. (2001). Tissue softening was observed in this work as a result of pectinolytic enzyme activities. This could result in the reduction of some contents of the cell wall, (such as galactan, araban and polyuronide); solubilization and partial depolymerization of some substances, all these lead to tissue maceration. These observations are in line with those of Hobson and Grierson (1993); Baiyewu (1994). Tissue maceration was also observed in this work due to the enzymatic activities of the pectin methyl esterase and polygalacturonase enzymes. This was found highest in infected than in healthy tubers because the tissues of the infected tubers were found macerated, wet and rotten to indicate the establishment of rot disease. This has been reported by Baiyewu (1994). These enzymes were also reported to catalyse the demethylation of the carboxylic group in the polygalacturonosyl residues as it was observed in this study as a form of wet rottening tissues.

Disintegration of the host's cell wall and the total collapse of the affected tissues were found in the infected cassava tubers used in this work especially in the Odongbo and TMS 4(2)1425 cultivars, where it was more severe than in others.
This has been discovered by Kawaimote and Lorbeer (1974) and Adewolu (1999) who opined that the infection of succulent stems results in the rapid breakdown of their tissues, resulting ultimately in the collapse of parenchyma cells and eventual maceration of the cells as well. Rot disease appeared to be typical of parenchyma and collenchyma in which they start by discolouration of the infected area, gradual softening and subsequent production of watery fluid with offensive smell (wet rot) while in some it will be the drying and hardening of the infected tissues (dry rot). This is found common especially in storage tissues such as cassava tubers used in this study where the wet rot was produced by Lasiodiplodia theobromae and Rhizopus stolonifer while the rot disease produced by Macrophomina phaseolina was dry with hard tissue (dry rot). This was discovered by Wood (1971); Adisa (1980); Duran and Mora, (1992); Odebode and Salami (2004).

The test pathogens used in this work were grown on basal medium containing soluble starch as the carbon source, and both the infected and healthy tubers produced enzymatic activities which indicate that secretion of enzymes is inductive (i.e. genetical) rather than being imposed. This was also reported by Oso (1979); Padmaja and Balagopal (1985); and Ajiboye (2004). These pathogens also grew well at different proportions on different carbon media which indicates preferential utilization of carbon sources used. This agrees with the findings of Weerasinghe and Naqvi (1985); and Popoola (2006) in their work on the physiological studies of some tubers. Enzyme activities of these test pathogens on the different carbon sources were also carried out and the results confirm the inductiveness of these enzymes.

Conclusively, this study reveals that tuber rot diseases of cassava are widely distributed especially in the areas surveyed and that infection of these 
tubers particularly the healthy tubers occur as a result of wound created on them, thus, harvested tubers should be handled carefully to prevent wounds. Tubers should also be used immediately after harvest and should not be kept for long time because tubers kept for long time still showed signs of deterioration.

Most importantly, tubers and the test pathogens (fungi) used were found to secrete enzymes involved in cell wall disintegration, this is an indication that enzymatic activities of cassava tubers could be more inductive than imposed. It can be recommended from this study that rodents that could create wounds should be kept away from tubers and that during harvesting and storage; tubers should be handled properly with care in order to prevent wounds and damage. They should also be properly arranged on logs of wood or rafters to avoid contact with soil.

\section{References}

Adewolu, A. K., 1999. Distribution, Cellular, Extra cellular Enzymes, and Control of fungi associated with post harvested rot of cassava (Manihot esculenta Crantz) in Southwestern Nigeria. Ph.D. Thesis, University of Ibadan, Ibadan, pp185.

Adisa, V. A. 1980. Post-Harvest rot of some fruits with particular reference to citrus species in Southwestern Nigerian $\mathrm{PhD}$ thesis, University of Ibadan, Ibadan, Nigeria.

Agrios, G. N. 1998. Plant Pathology. Third edition, Academic Press. New York.

Ajiboye, E. O. 2004. Effects of different nutrient sources on the growth of some post-harvest pathogens of cassava tubers.

M.Sc.Thesis,University of Ibadan Nigeria
Ampe, F. and A. Brauman. 1995. Origin of enzymes involved in detoxification and root softening during cassava retting. World Journal of Microbiology and Biotechnology 11:178-182.

Arinze, A. E. 1974. Studies on storage rot of sweet potato (Ipomea batatas) tubers in Nigeria. M.Sc. thesis, University of Lagos, Nigeria.

Awah, E. T. 1993. The effect of soil conditions on cassava pest. Paper prepared for presentation at the ecological sustainable cassava pest protection (ESCAPP) regional training workshop held in Cotonou, 10-22, January, 1994.

Baiyewu, R. A. 1994. Fungi associated with fruit rot of pawpaw (Carica papaya L.) in Southwestern Nigeria. PhD thesis, University of Ibadan, Ibadan, Nigeria.

Barnett, H. L. and B. Hunter. 1972. Illustrated Genera of imperfect fungi. Burgess Pub. Company, Minneapolis pp. 241.

Bernfield, P. 1951. Enzymes of starch degradation and synthesis advances. Enzymology related subject. Biochemistry 12:79-428.

Dahniya, M.T. 1994. An overview of cassava in Africa. African Crop Science Journal, 2(4):337-343.

Duran, J. A. and D. Mora. 1992. Diagnosis of postharvest diseases of pawpaw in Costa Rica II. Quantification and epidemiology of fruit diseases. Agronomia Costrarricense.12:(1)7-4.

Felix, I. N., R. Polson, and J. Stranss. 1999. Cassava Production trends in 
Africa. In: Tropical Root Crops in a developing economy edited by $\mathrm{F}$. Ofori and S.K. Hann. Proceedings of the $9^{\text {th }}$ Symposium of the International Society for Tropical Root Crops. Accra, Ghana.

Food and Agricultural Organisation 1991. FAO Production Yearbook, No45 FAO. Rome, Italy.

Food and Agricultural Organisation. 2000. FAO Production Year Book, Volume 54.

Hobson, G. E. and D. Grierson. 1993. Tomato In: Biochemistry of fruit ripening. Edited by G. Seymor, T. Taylor, and G. Tucker. Pub. Chapman and Hall London. pp. 405-442.

IITA. 1990. Cassava in Tropical Africa. A reference manual International Institute of Tropical Agricuture, Ibadan. pp. 176.

Ikotun, T., 1984. Pectolytic enzymes produced by Xanthomonas campestris pathovar cassava and their involvement in pathogenesis. Zeitschrift fur Allegemeine Mikrobiologie. 24:363-368.

Ingram, J. S. and J. R .O. Humphries. 1972. Cassava storage. A review. Tropical Science. 14:131.

Jansen, E. F. and L. R. Macdonell. 1945. Influence of methoxyl content on pectic substance on the action of polygalacturonase. Arch. Biochem. 8:113-118.

Kawaimote, S. O. and J. W. Lorbeer. 1974. Infection of onions by Baccillus caratovora. Techn. Bull. New York, S.E. Agric. Expt. Stn. 11:15-20.

Lealem, F. and B. A. Gashe. 1994. Amylase production by a gram positive bacterium isolated from fermenting Eragnosis tef. Journal of Applied Bacteriology 77: 348-352

Lozano, J .C. and R. H. Booth. 1974. Disease of cassava (Manihot esculenta Crantz.) PANS 20 (1): 30-54.

Nelson, N. 1994. A photometric adaptation of the Somogyi method for the determination of glucose. Journal of Biological Chemistry, USA 153: 375-380.

Odebode, A. C. and B. A. Oso. 1995. Enzyme activities during post-harvest storage of kolanut (Cola nitida) Schoot and Endlicher. Z. Lebensm Unters Forsch, 201: 555-556.

Odebode, A.C. and A.O. Salami. 2004. "Biochemical contents of pepper seedlings inoculated with Phytophthora infestans and arbuscular mycorrhiza”, Journal of Agricultural Sciences, 49(2): 251-257.

Odebode, A. C. and J. Sanusi. 1996. Influence of fungi associated with banana on nutritional content during storage. Z.lebensum. Unters. Forsch, 202: 471-473

Odebode, A. C. A. O. Salami and O. Osonubi. 2001. "Production of cell wall enzymes in pepper seedlings inoculated with arbusular mycorrhiza (Glomus etunicatum)", Tanzania Journal of Science 27: 1-8.

Odebode, A. C. A. O. Ladoye and O. Osonubi. 1997. Effect of Pythium aphanidermatum and the Arbuscular mycorrhiza fungus (Glomus deserticola) on disease severity and growth of pepper. International Journal of Tropical Plant Diseases 15:85-92.

Odebode, A. C. and K. Shehu. 2001. The effect of plant age and soil 
amendments on severity of Phytophthora root rot of pepper (Capsicum annum L.) in Southwestern Nigeria. International Journal of Tropical Plant Diseases. 47:363-369.

Oguntimehin, G. B. and I. Safarik. 1993. Comparison of spectrophotometric amylolytic assay. Nigerian Food Journal. 11:78-83.

Oladiran, A. O. and H. O. A. Oluma. 1990. Leaf spot of trifoliate yam (Dioscorea dumetonum Kunth) Pax. Betr. Trop. Landwirt. Vet. Med. 28:431-437.

Olsson, K. 1989. Relationship between pectolytic enzyme activity and rot development in potato tubers inoculated with Fusarium solani var. Caerulem J.Phytopathol. 124:225235.

Onyeocha, I. O. and C. I. Ogbonna. 1983. Extracellular enzyme production. A quick quantitative assay method. Nigerian Journal of Biotechnology. 1:48-59.

Ooshima, H., M. Sakara and Y. Harano. 1986 .Enhancement of enzymatic hydrolysis of cellulose by surfactants. Biotechnology and Bio- engineering, USA. 28: 1727-1734.

Oso, B. A. 1979. Mycelial growth and amylase production by Talaromyces emersonii. Mycologia. 3:520-529.

Padmaja, G., M. G. Moorthy, S. N. Zoe Bairibrigem, Vanessa Plumb, J. F. Wood and C. J. Powell. 1994. Nutritional evaluation of the starchy flour obtained from cassava tubers on fermentation with a mixed culture inoculum J. Agric. Food Chem. 42:766-770.
Padmaja, G. and C. Balagopal. 1985. Cellular and extracellular enzymes associated with postharvest deterioration of cassava tubers. Journal of Food Science and Technology. 22:83-87.

Paolo, A. and F. Franceso.1995. Pectin degrading enzymes and plant parasite interactions. European Journal of Plant Pathology. 101:365-375.

Pere-Artes, E. and M. Terra, 1989. Pectin enzymes from two races of Fusarium oxysporum F.sp. Ciceri. Enzyme production in culture and enzymatic activity on isolated chickpea cell wall. J. Phytopathology. 124:39-51.

Popoola, O. O. 2006. Thermal control effect on the incidence of some postharvest rot pathogens of Solanum tuberosum (L.) (Irish potato) and Ipomea batatas (Lam.) (Sweet potato). M.Sc.. Thesis, University of Ibadan, Ibadan, Nigeria. pp90.

Reese, J. E. and M. Mandels. 1963. Enzymic hydrolysis of cellulose and its derivatives. In: Methods in carbohydrates chemistry (Ed) Whitler London. pp. 139-143.

Rexova-Benkova, L. O. and Markovic. 1976. Pectic enzymes advances in carbohydrate. In: Methods in carbohydrates chemistry (Ed) Whitler. London. 139-143.

Salami A. O. 1999. Biochemical Interactions of Mycorrhiza and soilborne micro-organisms on growth of pepper (Capsicum annum (linn.)) seedlings. Ph.D. Thesis, University of Ibadan, Ibadan. pp. 165.

Salami, A. O. and O. Osonubi. 2002. Improving the traditional land-use system through agro- biotechnology: a case study of adoption of vesicular 
Emir. J. Food Agric. 2008. 20 (1): 01-17

http://www.cfa.uaeu.ac.ae/research/ejfa.htm

arbuscular mycorrhiza (VAM) by resource- poor farmers in Nigeria Tecnovation. 22(11): 725-730.

Salami, A. O. A. C. Odebode and O. Osonubi. 2001. Interactions of soil microorganisms on growth and disease incidence of pepper (Capsicum annum) Archives of Agronomy and Soil Science. 46:485492.

Salami. A. O. 2002 Influence of mycorrhiza inoculation on disease severity and growth of pepper (Capsicum annum) Linn International Journal of Tropical Plant Diseases. 17:51-60.

Somogyi, M J. 1952. Notes on sugar determination. Journal of Biological Chemistry, USA. 194:19-24.

Tella, T. O. 1991. Fungi associated with root rot of cassava. M.Sc. Thesis, University of Ibadan. Ibadan, Nigeria.

Therberge, R .L. 1989. Common African pests' diseases of cassava, yam, sweet potato and cocoyam. IITA Publication. pp. 108.

UNICEF/IITA 1989. Cassava: Lifeline for the Rural Household. Edited by
Natalie D.H. Intec. Printers Ltd. Ibadan.

Wanapat, M. O., A. Pimpa and U. Petlum. Boontao.1997. Cassava hay: A new strategic feed for ruminants during the dry season. Livestock Research for Rural Development, 9(2):

http://www.cipav.org.co/lrrd/lrrd9/2/ metha92.htm

Weerasingle, B. and S. H. Z Naqvi. 1985. Some comparative physiological studies on selected isolates of Botryodiplodia theobromae pat. causing storage rot of yams, cassava, and sweet potato in Nigeria. International Biodeterioration. 21(3):225-228.

Winstead, N. N. and J. C. Walker. 1954. Production of vascular browning by metabolites from several pathogens. Phytopathology. 44: 153-158.

Wood, R. S. K. 1971. The killing of plant cells by soft rot parasite. In: R.S. K. Wood, A. Bell and A. Graniti (Eds). Pp. 1-16. Phytoxins in plant disease. Academic press, London. 